
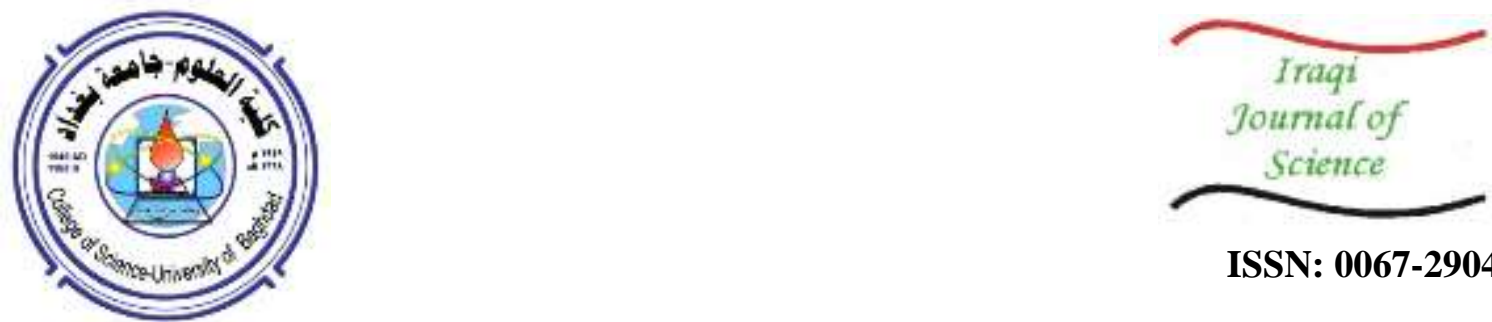

ISSN: 0067-2904

\title{
Neotectonic Activity of Segmented Alluvial Fans Along Hemr in South Anticline, East Iraq
}

\author{
Hala A. Al-Musawi ${ }^{1 *}$, Hamed H. Abdallah ${ }^{1}$, Thair M. Azzawi ${ }^{2}$ \\ ${ }^{1}$ Department of Geology, College of Science, University of Baghdad, Baghdad, Iraq \\ ${ }^{2}$ Department of Geography, Faculty of Education for Women, University of Baghdad, Baghdad, Iraq
}

Received: 10/9/2019

Accepted: 17/12/2019

\begin{abstract}
A quantitative analysis of geomorphic indices was carried out to understand the impacts of tectonics on the geomorphological relief of drainage basins and alluvial fans. Based on field work, satellite images and aerial photographs interpretation, five stages of alluvial fanswere recognized within the study area. Theyare of a coalesced type, forming continuous belt of Bajada, andcovering vast areas whichextend along the southwestern limb of Hemrinanticline. The alluvial fans' sediments lie unconformably over pre- Quaternary sediments represented by angular unconformity.The earlier stages of the fanswere developed during the PlioPleistocene age, whereas the later stage represents the sediments of the Holocene age. Fourdistinct segmented alluvial fans were considered under this study, located within Torsaq and Shosharin basins. They aredeveloped in the first, second and third stagesof alluvial fans. Some morphotectonic parameters were calculated in order to understand the tectonic dynamics of these fans, includingmountain front sinuosity (Smf), ratio of valley floor's width to height (Vf), fan tilting $(\beta)$, and drainage basin asymmetry (FA). The results showedless active mountain frontand low uplift,according to the acquired high values of Vf.The fansare tilted towards the west direction, indicating uplift of their eastern parts, whilethe main streams are shifted downstream to the right.
\end{abstract}

Keywords: Geomorphic indices, Fan segments, Mountain front, Fan tilting, Asymmetry factor.

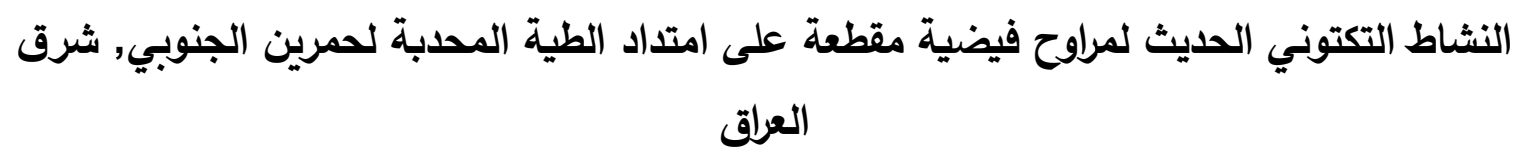

$$
\begin{aligned}
& \text { هالة عطاء الموسوي" }{ }^{*} \text { حامد حسن عبدالله 1, ثائر مظهر العزاوي2 } \\
& \text { قسم الجيولوجي ، كلية التربيه بنات، جامعة بغداد، بغداد، العراق } \\
& \text { الخلاصه } \\
& \text { تم دراسة التحليل الكمي للمؤشرات الجيومورفولوجية لفهم التاثير التكتوني على احواض التصريف } \\
& \text { والمراوح الفيضية بالاعتماد على العمل الحقلي,و تفسير الصور الفضائية و الصور الجوية حيث تم } \\
& \text { تمييز خمسة مراحل للمراوح الفيضية والمتصلة مع بعضها مكونة حزام من البجادا على امتداد }
\end{aligned}
$$

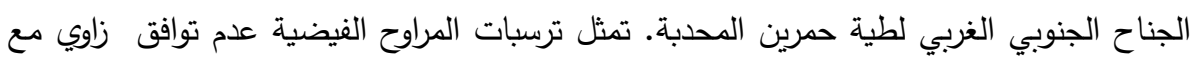




$$
\begin{aligned}
& \text { ترسبات ما قبل العصر الرباعي. تطورت المرحلة الاقدم من المراوح الفيضية في عمر البلايو- } \\
& \text { لايستوسين بينما تكونت المراحل الحديثة في عمر الهولوسين. } \\
& \text { تم التركيز على اربعة مراوح فيضية مقطعة تقع في حوضي ترساق و شوشرين تطورت ضمن } \\
& \text { المراحل الاولى, الثانية والثالثة للمراوح الفيضية وتم حساب بعض المعاملات المورفوتكتونية مثل دالة } \\
& \text { التعرج, عرض قاع الوادي نسبة الى ارتفاعه, ميل المروحة و تماثل حوض التصريف. اثبتت النتائج }
\end{aligned}
$$

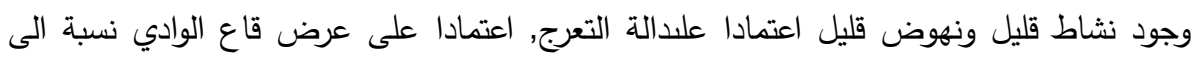

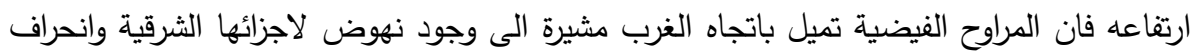

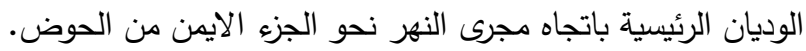

\section{INTRODUCTION}

Alluvial fans are a conspicuous conical and depositional landform deposited by a river when its flow is suddenly slowed [1,2]. They areformed at the base of foothills due to the material accumulation, where the load, consisting of fine and coarse size, is coming from upstream and deposited at the point of break in slope.

The size of the accumulation of sediments decreases outward from the apex toward the outer margins of the fans [3]. Their transverse profile is arched and the longitudinal profile is slightly concave, with slopes are usually less than $10^{\circ}[4]$.

The geometry and development of fans are mainly controlled by the relating factors such asrelief, slope, climate, lithology and tectonic activity [2,5].The sources of the flows are from a single point located at the apex of the fan, which over time move to occupy different positions on the fan surface[6]. A canyon draining from mountainous terrain emerges out into a flatter plain, then alluvial fans are formed. A Bajada or a compound alluvial fan is formed when alluvial fans converge with neighboring alluvial fans into a single apron of deposits against a slope.

The fan shape can be explained as the system which includes the accumulated sediments at the apex of the fan will tend to a state minimizing the sum of the transport energy that is involved in moving the sediment and the gravitational potential of material in the fan. Iso-transport energy lines will be formed in the form of concentric arcs radiating from the discharge point at the apex of the fan. Therefore, the material will tend to be deposited equally about these lines, giving the sediments the characteristic fan shape.

\section{Location of the Study Area}

The study area represents the eastern part of Wasit Governorate, near the Iraqi- Iranian international borders. It occupies an area of about $2000 \mathrm{~km}^{2}$ (Figure-1).Zurbatiyatownis within the study area, which contains Torsaq and Shosharin drainages as the main basins. The areais limited by the following coordinates:

Longitude $45^{\circ} 05^{\prime} 00^{\prime \prime}, 46^{\circ} 00^{\prime} 00^{\prime \prime}$ Latitude $32^{\circ} 75^{\prime} 00^{\prime \prime}, 33^{\circ} 06^{\prime} 00^{\prime \prime}$. 


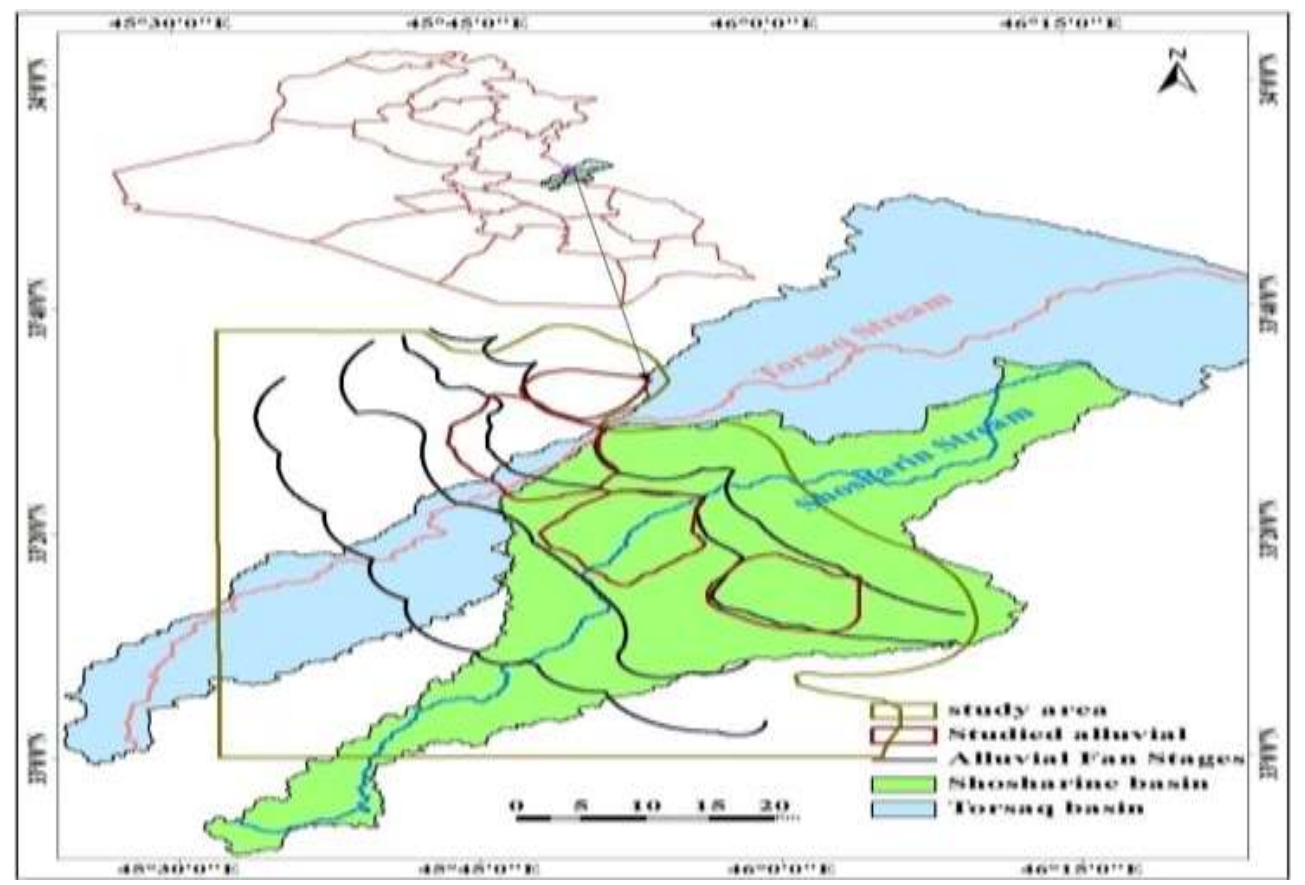

Figure 1- Location map of the study area

\section{Geological Setting}

Stratigraphically, different sedimentary formations of different lithological constituents and ages (Oligocene- Pliocene) are exposed within the study area, in addition to various types of Quaternary sediments (Figure-2). A brief description of the lithological units is mentioned hereinafter(from older to younger).

- Ibrahim Formation (LateOligocene):This formation represents the oldest rock unit within the hanging wall of Koolic thrust fault, which is thrusted on Dhiban and Jeribe formations (foot wall). It is exposed within the eastern part of the study area. It comprises $130 \mathrm{~m}$ of alternation of marl and marly limestone. The upper part of the formation is dominated by marl with thin beds of limestone, while the middle part is composed of thick bed of marly limestone. The lower part consists of an alternation of marly limestone and marl [7].

- Serikagni Formation (Early Miocene): It is exposed in the eastern parts of the study area, consistingof $22 \mathrm{~m}$ of marl, marly limestone and limestone.

- Dhiban Formation (Early Miocene): It is exposed within in the eastern parts of the study area, consistingof $30 \mathrm{~m}$ of white, nodular textured and massive gypsum.

- Jeribe Formation (Middle Miocene): It is exposed as relics along the thrust fault and in the core of Koolic anticline. Itcomprisesof $70 \mathrm{~m}$ of massive dolomitic limestone.

- Fatha Formation (Middle Miocene): The formation consists of cyclic an alternation of calcareous claystone, limestone and gypsum. It is divided into two members [8]; both upper and lower members of this formation are exposed in the study area. Its maximum exposed thickness is $330 \mathrm{~m}$. Fatha Formation is thrusted over Injana Formation along the major thrust fault.

- Injana Formation (Late Miocene):The formation is exposed only within the southwestern limb of Hemrin South anticline. Injana formation consists of an alternation of claystone, siltstone and sandstone.The uppermost part is characterized by very thick (up to $30 \mathrm{~m}$ ) claystone and thin sandstone beds. The total thickness is $350 \mathrm{~m}$.

- Mukdadiyah Formation (Late Miocene-Pliocene): It consists of $110 \mathrm{~m}$ of rhythmic clastic cycles of sandstone and claystone, which are lenticular as a mode of thedeposition, with many lateral changes to each other.

- Bai Hassan Formation (Pliocene - Pleistocene): The formation consists of thick and coarse conglomerates thatcontain lenses of sandstone.The total exposed thickness is $25 \mathrm{~m}$ [7].

Tectonically, the Zagros Fold- Thrust Belt within Iraq is divided into several NW-SE trending longitudinal tectonic zones $[9,10]$. The Low Folded Zone represents a part of the Outer Platform of the Arabian plate [11], where the study area lies. The main structures within the study area are: 
Hemrin South anticline. Itis the major anticline within the study area. It is a NNW-SSE trending anticline, $33 \mathrm{~km}$ in length and its width ranges from $0.7 \mathrm{~km}$ up to $7 \mathrm{~km}$. The NE limb of Hemrin South anticline is thrusted over its $\mathrm{SW} \operatorname{limb}[12]$.

KaniSakht anticline. Itis a narrow asymmetrical anticline, located along the northeastern limb of Hemrin South anticline, with a length of about $30 \mathrm{~km}$ and variable widths of up to $1.5 \mathrm{~km}$. It has a NWN - SES trend. The dip of the southwestern limb ranges $40^{\circ} 65^{\circ}$, whereas the dip of the northeastern limb ranges $47^{\circ}-52^{\circ}$. The study area is characterized by the existenceof three large scale thrust faults of a NW - SE trend; these are Kachaa Fault which extends over25 km in length, Cea Koran Fault which extends of $25 \mathrm{~km}$ in length, and Koolic Fault which runs parallel to the Iraqi Iranian international borders and extends over $12 \mathrm{~km}$ in length [7].

The study area represents the extreme margin of the Low Folded Zone, which is physiographically known as the Foothill Zone, located between High Amplitude Mountainous and Mesopotamian Plain provinces of Iraq [13]. From the topographic point of view, the study area descends in relief from its northeastern part, where the mountainous area exists, towards W and SW parts, where alluvial fans and sheet run off sediments are well developed. Geomorphologically, the area is dissected by three main streams which have similar characters and behaviors. They are characterized by narrow and deep courses after leaving the alluvial fans and drain within the Tigris River and Hore Al-Shuwaicha depression. The main geomorphological units in the study area are:1- Units of Structural Denudational origin, which include fault escarpments, hogbacks and cuestas.2- Units of Fluvial origin, developed as numerous alluvial fans, which are divided into three types depending on the lithological composition of the sources; the first consists of alluvial fans composed of conglomerate, the second consists of carbonate conglomerate, and the last consists of gypcrete mixed with gravels and rock fragments [7].

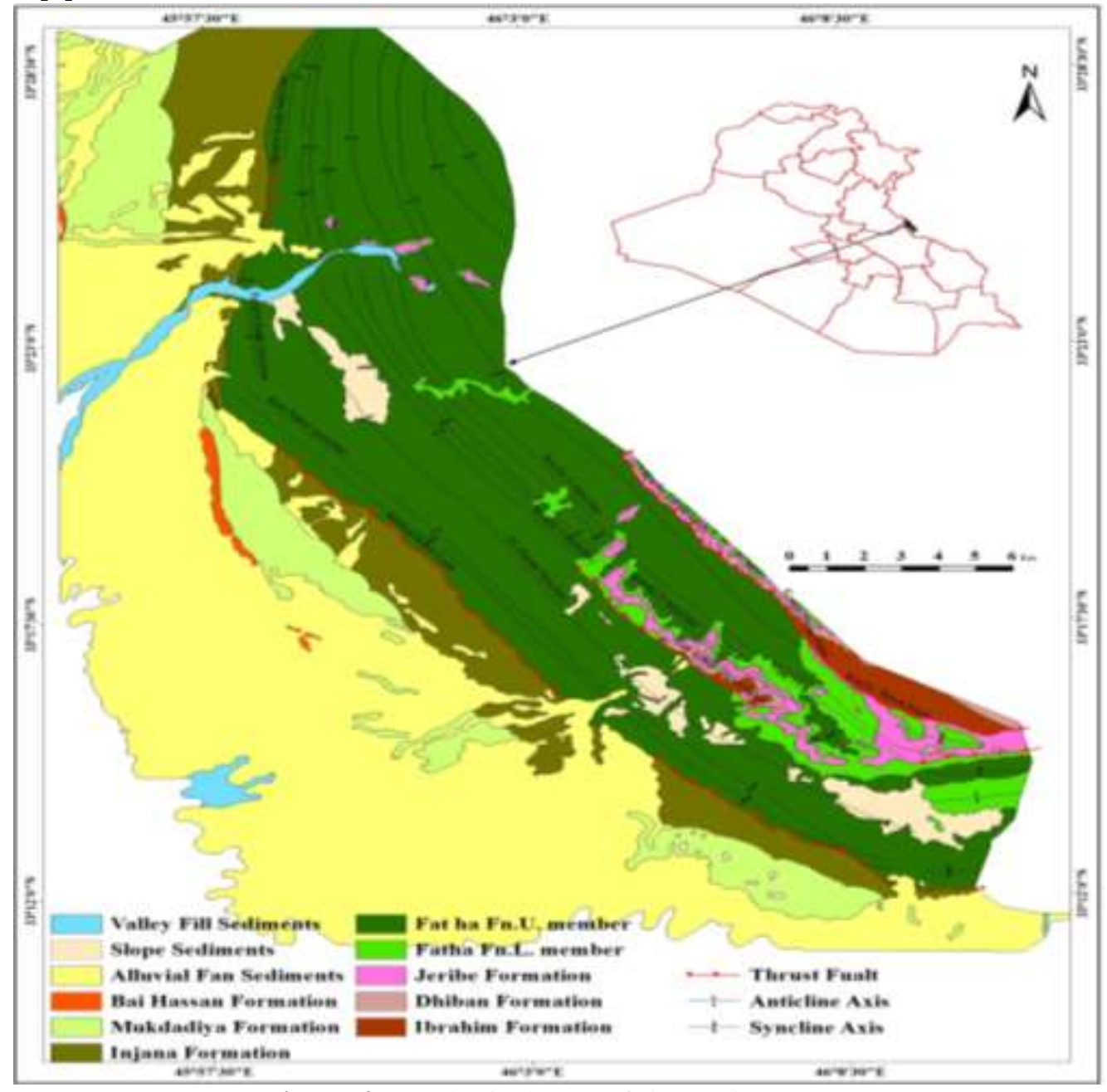

Figure 2- Geological map of the study area[7] 


\section{Methodology}

This st udy is based on intensive field work and interpretation of $30 \mathrm{~m}$ and $12.5 \mathrm{~m}$ resolution digital elevation model (DEM), Landsat image (14 m), aerial photographs of scale 1:35000 and topographical maps of scale 1:25000. These data were used for deducing the geomorphological and morphotectonic analyses of the alluvial fans. The morphological parameters of the alluvial fans,such aslength, width, area and slope angle were calculated by GIS program.

Four different morphotectonic indices are indicated to evaluate comparative degrees of tectonic activity in the study area;These are: 1)mountain front sinuosity (Smf), 2) 'sratio of valley floor width to height (Vf), 3)drainage basin asymmetry (FA), 4)the tectonic tilt of the fans (Table-1), which were calculated according to the methodology proposed earlier[14].

Table 1- Geomorphic indices used in this study [14]

\begin{tabular}{|c|c|}
\hline Index & Equation \\
\hline Mountain front sinuosity (Smf), & $\mathrm{S}_{\mathrm{mf}}=\mathrm{L}_{\mathrm{mf}} / \mathrm{L}_{\mathrm{s}}$ \\
\hline Ratio of valley floor width to height $(\mathrm{Vf})$ & $\mathrm{V}_{\mathrm{f}}=2 \mathrm{~V}_{\mathrm{fw}} /\left[\left(\mathrm{E}_{\mathrm{id}}-\mathrm{E}_{\mathrm{sc}}\right)+\left(\mathrm{E}_{\mathrm{rd}}-\mathrm{E}_{\mathrm{sc}}\right)\right]$ \\
\hline Fan tilting $(\beta)$ & $\left.\beta=\arccos \left((\mathrm{b} / \mathrm{a})^{2} \sin ^{2} \alpha+\cos ^{2} \alpha\right)\right)^{0.5}$ \\
\hline Drainage basin asymmetry (AF) & $\mathrm{AF}=100(\mathrm{Ar} / \mathrm{At})$ \\
\hline
\end{tabular}

\section{Alluvial Fans in the Study Area}

Two large fans can be recognized in the study area; these are:1) Torsaq Alluvial Fan which is developed from Torsaq stream, and 2) ShoSharin Alluvial Fan which is developed from Shosharin stream. Five stages of alluvial fan can be recognized within the study area (Figure-3). They lie unconformably over thepre-Quaternary sediments with angular unconformity. The fan shapes are unified,represented by delta shape and typical concave tops. The earliest stage (first stage) was developed during the Plio-Pleistocene age, whereas the later stage (fifth stage) represents the sediments of the Holocene age [15].The alluvial fan sediments are composed of unsorted rock fragments cemented by calcareous materials. The fragments are rounded to sub-rounded with different sizeswhich range from few centimeters up to large boulders. They are mainly of carbonate rocks covered by secondary gypsum forms in gypcrete crust. The exposed thickness ranges from $20 \mathrm{~m}$ in Shosharin alluvial fan to $25 \mathrm{~m}$ in Torsaq alluvial fan [7]. The five stages were differentiated according to their geomorphic positions, lithological variations, and weathering rate and intensity.

Shosharin 1 and Shosharin 2 segments are developed in Shosharin basin and located in the second and third stages of alluvial fans. They have different extensions and sizes, their area ranges $55-150$ $\mathrm{km}^{2}$, with a maximum width ofup to $16 \mathrm{~km}$ and a length of $9-14 \mathrm{~km}$. Their slopes have a gentle surface that ranges $8-15^{\circ}$ towards southwest(Table-2).

\section{Geomorphic Indices}

Mountain Front Sinuosity Index $\left(\mathbf{S}_{\mathrm{mf}}\right)$

Mountain front sinuosity $\left(\mathrm{S}_{\mathrm{mf}}\right)$ is defined by the equation:

$$
\mathrm{S}_{\mathrm{mf}}=\mathrm{L}_{\mathrm{m} f} / \mathrm{L}_{\mathrm{s}}
$$

where $\mathrm{S}_{\mathrm{mf}}$ is the mountain front sinuosity, $\mathrm{L}_{\mathrm{mf}}$ is the length of mountain front along the foot of the mountain along a contour line, and $\mathrm{L}_{\mathrm{s}}$ is the straight-line length of the mountain front along the same contour line. This index reflects the balance between erosion and active vertical tectonic. Active fronts show straight profiles and low values of $S_{\mathrm{mf}}$, whereas inactive or less active fronts show irregular profiles and high values of $S_{\mathrm{mf}}$. Generally, the majority of the straight mountain fronts are bounded by major faults [16].According to a previous work[17], $\mathrm{S}_{\mathrm{mf}}$ is classified into three classes; thefirst ranges1.0-1.6 and associated with the most active mountain front, the second s ranges 1.6-3.0 and is less active, and the thirdranges 3.0- 5.0 and indicates inactive mountain fronts. 


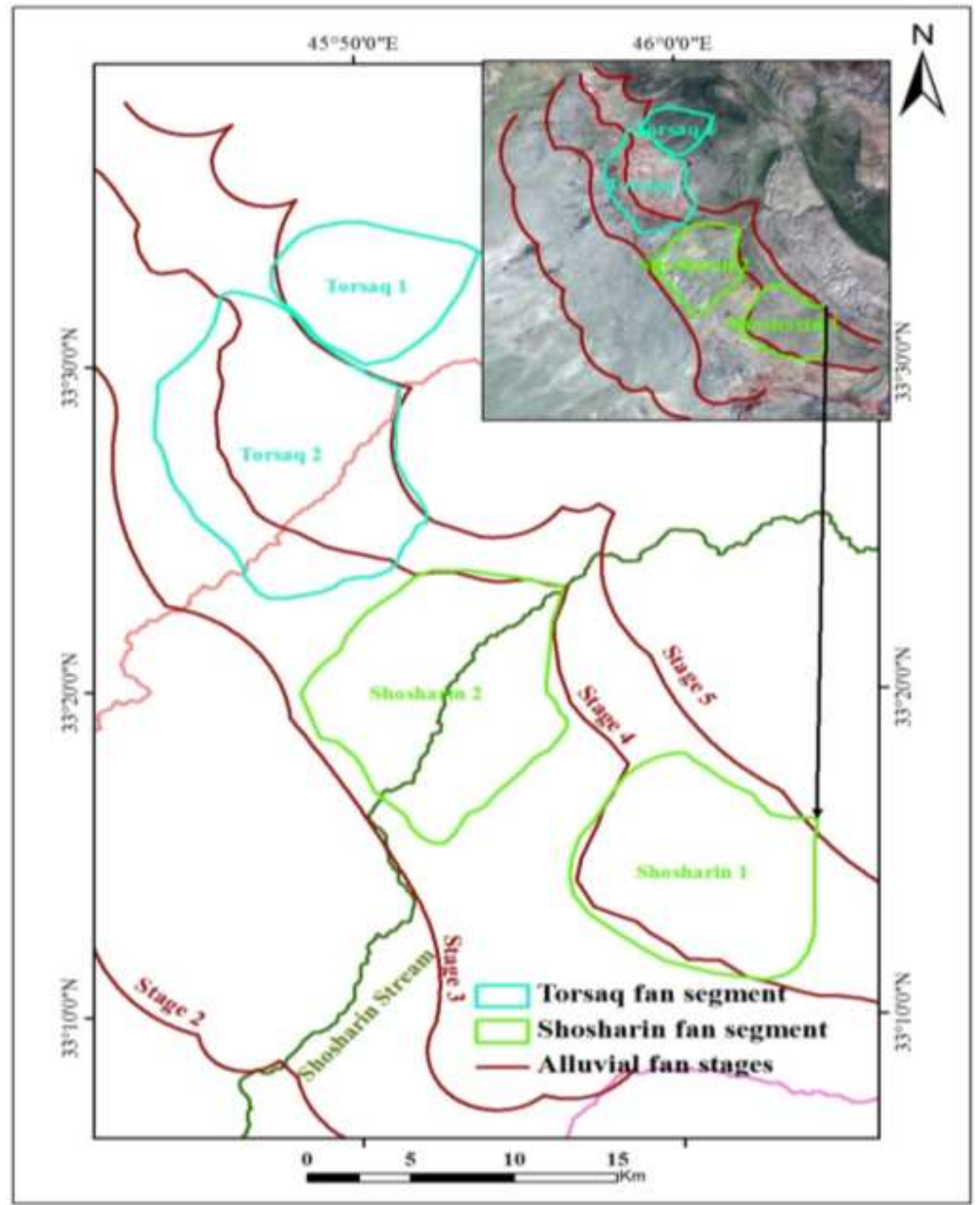

Figure 3-The studied alluvial fans.

Table 2- Geometry of the studied alluvial fans.

\begin{tabular}{|c|c|c|c|c|c|}
\hline Fan Segment & Fan Stage & $\begin{array}{c}\text { Total } \\
\text { Area }\left(\mathrm{Km}^{2}\right)\end{array}$ & $\begin{array}{c}\text { Width } \\
(\mathrm{Km})\end{array}$ & Length $(\mathrm{Km})$ & Slope \\
\hline Torsaq1 & Stage 1 & 55 & 8 & 9 & $10-15^{\circ}$ \\
\hline Torsaq2 & Stage 2 & 150 & 16 & 12 & $8-12^{\circ}$ \\
\hline Shosharin1 & Stage 2 & 110 & 13 & 11 & $8-10^{\circ}$ \\
\hline Shosharin2 & Stage 3 & 130 & 12 & 14 & $9-11^{\circ}$ \\
\hline
\end{tabular}

In the study area, five mountain front segments are drawn along the main Katchaa thrust fault

(Figure-4). Their values range 1.04 - 1.52 which reflects an active tectonic mountain front (Table-3). 


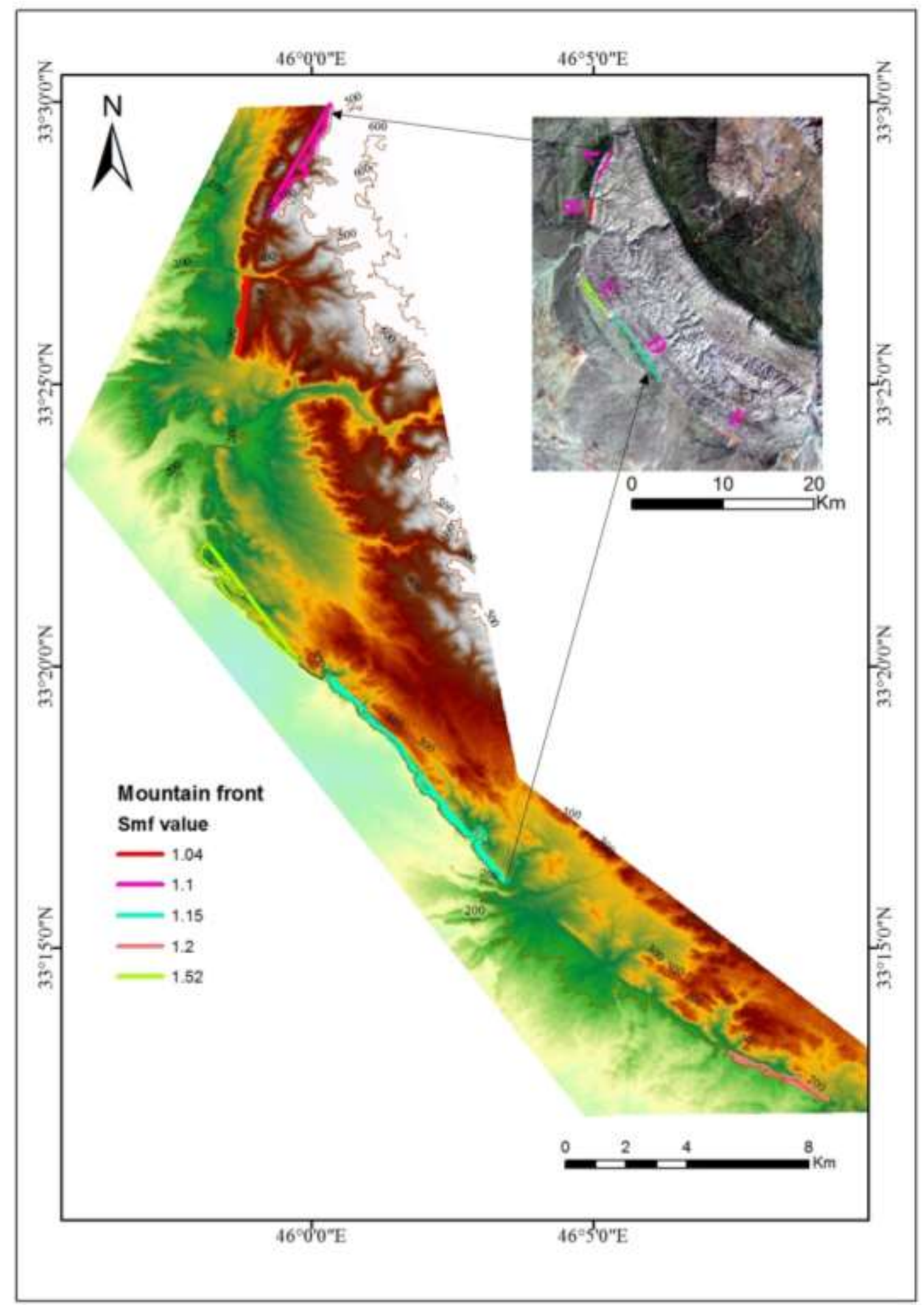

Figure 4- Mountain front segments in the study area.

Table 3- Measured mountain front sinuosity values within the study area.

\begin{tabular}{|c|c|c|c|c|}
\hline Segment & $\mathrm{L}_{\mathrm{mf}}$ & $\mathrm{L}_{\mathrm{s}}$ & $\mathrm{S}_{\mathrm{mf}}(\mathrm{km})$ & Tectonic activity \\
\hline $\mathrm{A}$ & 4.484 & 4.045 & 1.11 & Active \\
\hline $\mathrm{B}$ & 2.594 & 2.480 & 1.04 & Active \\
\hline $\mathrm{C}$ & 6.940 & 4.574 & 1.52 & Active \\
\hline $\mathrm{D}$ & 9.626 & 8.357 & 1.15 & Active \\
\hline E & 3.716 & 3.127 & 1.19 & Active \\
\hline
\end{tabular}




\section{Ratio of Valley Floor Width to Valley Height $\operatorname{Index}\left(\mathbf{V}_{\mathbf{f}}\right)$}

Valley floor width to valley height ratio is calculated by the following equation:

$$
\mathrm{V}_{\mathrm{f}}=2 \mathrm{~V}_{\mathrm{fw}} /\left(\mathrm{E}_{\mathrm{id}}-\mathrm{E}_{\mathrm{sc}}\right)+\left(\mathrm{E}_{\mathrm{rd}}-\mathrm{E}_{\mathrm{sc}}\right)
$$

where $V_{f w}$ is the width of the valley floor, $E_{r d}$ and $E_{i d}$ are the elevations of the right and left valley divides facing downstream, and $\mathrm{E}_{\mathrm{sc}}$ is the elevation of the valley floor. This index differentiates between theU-shaped valleys (broad floored) and the V-shaped valleys. Thus Vfcan be classified as Vshaped valleys which has $\mathrm{V}_{\mathrm{f}}$ values $<1.0$, with an active stream incision associated with high uplift rates. Values between 1.0 and 1.5 reflect moderately active tectonics, and values $>1.5$ are classified as $\mathrm{U}$-shaped valleys associated with low uplift rates $[17,15]$. Values of $\mathrm{V}_{\mathrm{fw}}>1.5$ also mark lateral erosion due to the stability of base level or tectonic quiescence [18].Vf values vary depending on stream discharge, catchments sizes, and rock type [19].

Three different transverse profiles across the main course of Shosharin and Torsaq basins were calculated ,namely A-B, C-D, and E-F (Table-4 and Figure-5). The localities of the profiles were selected according to the distance to the main thrust, where A-B is near the thrust, whereas the other two profiles are located in the alluvial fan area.

The ratio of valley floor's width-to-height of the three profiles in Shosharin basin showed high values of 2.4, 27.2 and 28.5, which indicate that all the tributaries in Shosharin basin reflect growth of U-shaped valleys associated with low uplift [15].

The calculated values of $\mathrm{V}_{\mathrm{f}}$ in Torsaq basin are variable, being 1.4 in the profile A- B,which reflects the growth of deep or V-shaped valley associated with uplift, whereas the values in C-D and E-F profiles are 26.3 and 17.24, respectively,which indicate U-shaped valleys associated with low uplift rates.

Table 4- Measured values of valley floor width to valley heightwithin the study area.

\begin{tabular}{|c|c|c|c|c|c|c|c|}
\hline \multirow{3}{*}{ Basin } & Profile & $\begin{array}{c}\mathrm{V}_{\mathrm{fw}} \\
(\mathrm{m})\end{array}$ & $\mathrm{E}_{\mathrm{sc}}(\mathrm{m})$ & $\mathrm{E}_{\mathrm{ld}}(\mathrm{m})$ & $\mathrm{E}_{\mathrm{rd}}(\mathrm{m})$ & $\mathrm{V}_{\mathrm{f}}$ & $\begin{array}{c}\text { Tectonic } \\
\text { activity }\end{array}$ \\
\hline \multirow{3}{*}{ Torsaq } & A- B & 200 & 260 & 300 & 500 & 1.4 & Moderate \\
\cline { 2 - 8 } & C- D & 50 & 68 & 69.8 & 70 & 26.3 & Low \\
\cline { 2 - 8 } & E- F & 100 & 30.7 & 36 & 37 & 17.2 & Low \\
\hline \multirow{3}{*}{ Shosharin } & A- B & 500 & 280 & 550 & 420 & 2.4 & Low \\
\cline { 2 - 8 } & C- D & 750 & 105 & 140 & 125 & 27.2 & Low \\
\cline { 2 - 8 } & E- F & 100 & 40 & 45 & 42 & 28.5 & Low \\
\hline
\end{tabular}
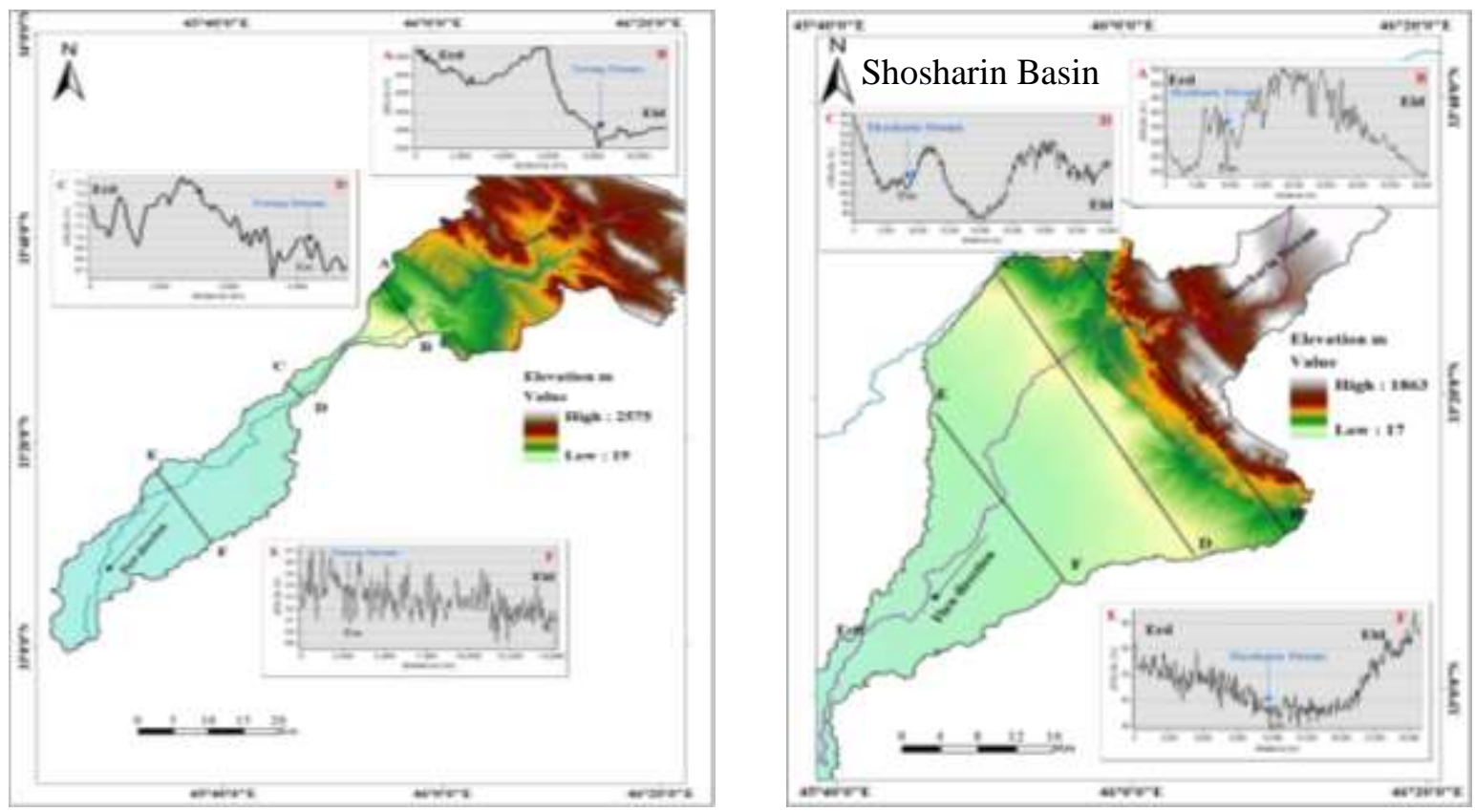

Figure 5-Transverse profiles of Torsaq and Shosharin basins. 


\section{Fan Tilting}

Simple alluvial fans are symmetrical half coneswith approximately circular topographic contour lines in the absence of tilting, whereas in case of tectonic tilt, the contour lines across the fan represent segments of ellipses with long axes parallel to the tilt direction. The amount of the tilt can be measured by the following equation[15]:

$$
\left.\beta=\arccos \left\{(b / a)^{2} \sin ^{2} \alpha+\cos ^{2} \alpha\right)\right\}^{0.5}
$$

where $\alpha$ is the original depositional slope, which is derived by measuring the slope along the minor axis of the ellipse, bis the half of the length of the minor axis of the ellipse, and ais the half of the length of the major axis of the ellipse.

In the study area, the tilting was calculated for the four alluvial segments. The results of fans tilting are shown in Table-5.

Table 5- The data of fan tilt in the studied alluvial fans within the study area.

\begin{tabular}{|c|c|c|c|c|}
\hline Fan name & b (m) & a (m) & $\alpha$ & $\beta$ (degree) \\
\hline Torsaq1 & 17.246 & 17.331 & 1.03 & $0.57^{\circ}$ \\
\hline Torsaq2 & 21.942 & 22.520 & 0.25 & $0.77^{\circ}$ \\
\hline Shosharin1 & 23.710 & 24.177 & 0.23 & $0.85^{\circ}$ \\
\hline Shosharin2 & 19.440 & 19.627 & 0.35 & $0.73^{\circ}$ \\
\hline
\end{tabular}

The angle of tilting in Shosharin 1 and 2 fan is $0.85^{\circ}$ and 0.73 , whereas it is $0.57^{\circ}$ in Torsaq 1 and $0.77^{\circ}$ in Torsaq 2. The tilting in all fans is towards the west direction(Figure-7), indicating uplift of their eastern parts. This uplift canbe attributed to the neotectonics of the thrusting uplift along Katchaa thrust fault, due to the collision of the Arabian- Iranian plates.

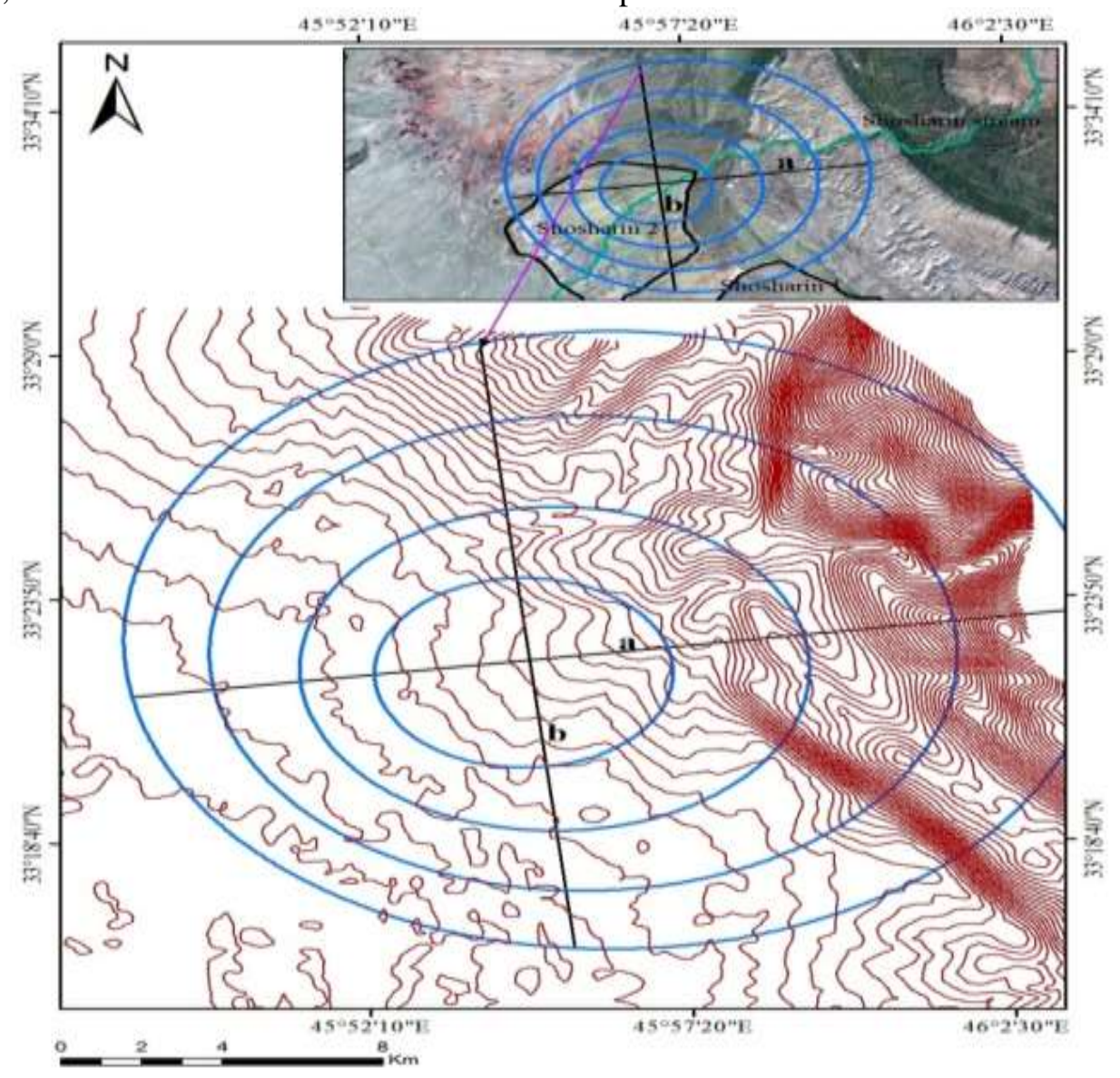

Figure 7-Fit ellipses on elevation contours of the Shosharin 2 fan; a and $b$ are the major and minor axes of the ellipse. 


\section{Drainage Basin Asymmetry Factor (AF)}

This factor is used to identify tectonic tilting of the basin $[15,20]$. This factor is defined as AF = 100(Ar/At)

where $\mathrm{Ar}$ is the drainage basin area to the right of the trunk stream (facing downstream) and At is the total area of the drainage basin. Values of AF close to or equal to 50 indicate little or no tilting,i.e. a symmetric basin.AF values greater or lower than 50may reflect asymmetry resulting from lithological control, tectonic tilting, or differential erosion [15].

Two basins were analyzed in the present study, namelyShosharin and Tarsaq. The calculated values of AF of Torsaq and Shosharin basins are equal to 46.33 and 38.28, respectively, which indicate that the main streams are shifted downstream to the right and tilted towards northwest(Figure-8).

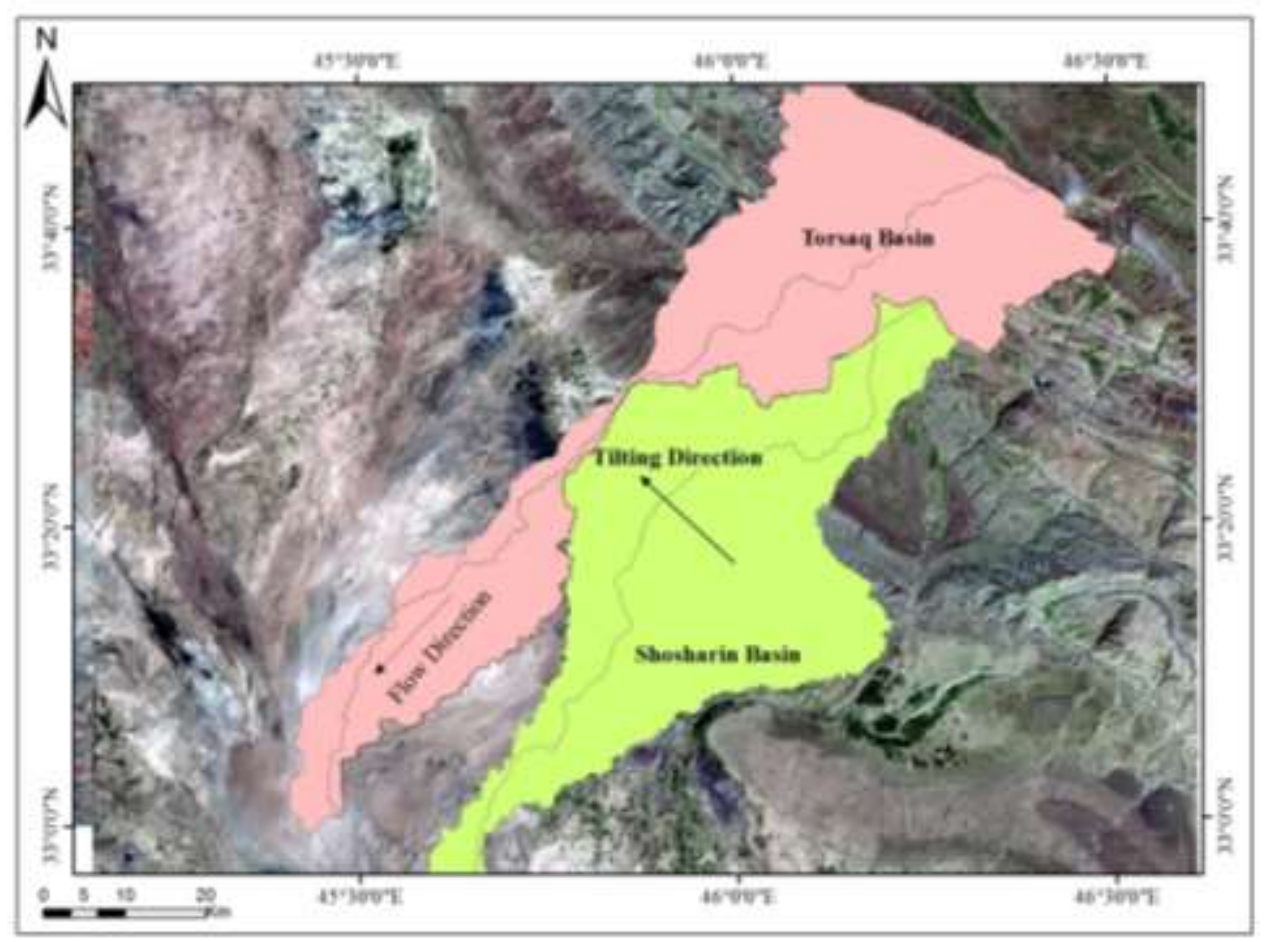

Figure 8-Drainage Basin asymmetry of Torsaq and Shosharin basins.

\section{CONCLUSIONS}

The study area is located within two tectonic zones; i- Low Folded Zone which extends along the northern and northeastern parts and characterized by the existence of several regional folds, faults, and tectonic activity. ii- The majority of the study area is located within the Mesopotamian Zone which is characterized by thick Quaternary sediments and low tectonic activity. The existence of very narrow areas in the middle part of each basin is due to the formation of a very deep gorge. Tectonically,the area is active due to the Smf values of five marked mountain front segments drawn along the main Katchaa thrust fault, which have the range of 1.04 - 1.52. Most of the valley floors have a wide range of50 - $200 \mathrm{~m}$ in Torsaq basin and $150-750 \mathrm{~m}$ in Shosharin basin. It is notable that Vf values are high and they are increased with the flow direction away from the main thrust. Thus, the valley floor's width-to-depth ratio in the Shosharin and Torsaq basins show high values, which reflect the growth of U-shape valleys which is a clear indication of low uplift. An exception is one profile (A- B in Torsaq basin) which reflects the growth of deep or V-shaped valley associated with uplift,which is due to the close distance to the main thrust.

There is an inverse proportionality relationship between area and slope of the fans; Torsaq 1 is the smallest and steepest segment fan, whereas Torsaq 2 is the largest and gentlest. The fans are tilted towards the west direction,indicating uplift of their eastern parts. The values of drainage basin asymmetry (AF) in the studied basins are equal to 46.33 and 38.28 , which indicate that the main streams are shifted downstream to the right and tilted towards northwest. According to the values of 
drainage basin asymmetry and the fan tilting, it is concluded that there is an uplifted zone with West and Northwest directions.

\section{Acknowledgments}

It is worthy to mention that the authors sincerely express their gratitude and thanks to the Iraq Geological Survey (GEOSURV) for the unlimited logistical support that was offered during the field work and providing all available data that are required for the achievement of this study, also deepest thanks to Mr. Varoujan Sissakian (retired expert) for his scientific support, inspiration and multiple efforts.

\section{REFERENCES}

1. Burbank, D.W. and Anderson, R.S. 2001. Tectonic Geomorphology. Blackwell ScienceOxford.

2. Rahman, S. 2016. The formation and morphological characteristics of alluvial fan deposits in the Rangpo basin sikkim,European Journal of Geography, 7(3): 86 - 98.

3. Singh, S. 2007. Geomorphology. FifthEdition. Prayag Pustak Bahawan, Allahabad, India.

4. Sissakian, V.K., Al- Mousawi, H., Al-Ansari and Knutsson, S. 2015. Old alluvial fan relics in North and Northeast Iraq, Journal of Earth Sciences and Geotechnical Engineering, 5(2): 45-62.

5. Bahrami, S. 2013. Tectonic controls on the morphometry of alluvial fans around Danehkhoshk anticline, Zagros, Iran,Geomorphology, pp: 217-230.

6. Huggett,R. J.2007. Fundamentals of geomorphology. Taylor and Francis Group.

7. Mahmoud, A. A., Ali, M. A., Mohammed, A. J., Al-Mikhtar, L. E., Al-kubaysi, K. N.,Hussien, M. S., Al- Obaidy, R. A., Mohammed Ali, S. M., Tawfeeq, G., Jassim, M. K., Shnaen, S. R. and Kareem, A. Y. 2018. Detailed geological mapping of Iraq, Zurbatiyah region, east Iraq, scale 1:250000. Iraq-Geosurv. Int. rep. no. 3650.

8. Al-Mubarak, M. A. and Youkhanna, R. Y.1976. Report on the regional geological mapping of AlFatah-Mosul Area. Iraq- Geosurv.Int. rep. no. 753.

9. Buday, T. and Jassim, S., Z. 1987. The Regional Geology of Iraq. Vol. 2, Tectonism,Magmatism and Metamorphism. GEOSURV, Baghdad.

10. Fouad, S. F.A. 2012. Western Zagros Fold- Thrust Belt, Part I, The Low Folded Zone. Iraqi Bulletin of Geology and Mining, Special Issue(5): 39-62.

11. Jassim, S. Z. and Goff, J. C. 2006. Geology of Iraq. Prague and Moravian Museum,Brno.

12. Al-Shwaily, A.Kh. and Al-Obaidi, M.R. 2018. Determination of the paleostress magnitude of the eastern part of the low Folded Zone, East Iraq. Indian journal of natural sciences, 9(50): 1514515160.

13. Yacoub, S. Y., Othman, A. A. and Kadim, T. H. 2012. Geomorphology of the LowFolded Zone. Iraqi Bulletin of Geology and Mining, Special Issue (5): 7-37.

14. Keller, E.A. and Pinter, N.2002. Active Tectonics: Earthquakes, Uplift, and Landscape. Second Edition. Englewood Cliffs, New Jersey, Prentice Hall.

15. Yacoub, S. Y.1983.The Geology of Mandali Area Sheet No. NI-38-11, the Mesopotamian Plain Project. Iraq-Geosurv. Int. rep. no. 1383.

16. Ahmad, Sh., Alam, A., Ahmad, B., Afzal, A., Bhat, M.I., Bhat, M. S., and Ahmad, H., F.2018. Tectono-geomorphic indices of the Erin basin, NE Kashmir valley, India. Journal of Asian Earth Sciences, 151: 16-30.

17. Bull, W. B. and McFadden, L. D. 1977. 'Tectonic geomorphology north and south of the Garlock Fault, California', in Doehring, D. O.(Ed.), Geomorphology in Arid Regions, Proceedings of Eighth Annual Geomorphology Symposium, State University of New York, Binghamton, 115138.

18. Goswami, P. K, Pan, C. and Pandey, S. 2009. Tectonic controls on the geomorphic evolution of alluvial fans in the Piedmont Zone of Ganga Plain, Uttarakhand, India, Journal of Earth Syst. Sci, 118(3): 245-259.

19. Khalifa, A., Cakir, Z., Owen, L. and Kaya,S. 2018. Morphotectonic analysis of the East Anatolian Fault, Turkey,Turkish Journal of Earth Sciences, 27: 110-126.

20. Matoš, B. 2014. Neotectonic and Recently Active Faults in Bilogora Mountain Area and Assessment of their Seismogenic Potential. Ph.D. Thesis, University of Zagreb, Faculty of Mining, Geology and Petroleum Engineering, Zagreb. 